\begin{tabular}{c|c|c}
\hline \hline & MARINE ECOLOGY PROGRESS SERIES \\
Mol. 231: 269-277, 2002 & Mar Ecol Prog Ser & Published April 22 \\
\hline \hline
\end{tabular}

\title{
Foraging niches of three Diomedea albatrosses
}

\author{
D. G. Nicholls ${ }^{1, *}$, C. J. R. Robertson ${ }^{2}$, P. A. Prince ${ }^{3, \mp}$, M. D. Murray ${ }^{4}$, K. J. Walker ${ }^{5}$, \\ G. P. Elliott ${ }^{5}$ \\ ${ }^{1}$ Chisholm Institute, PO Box 684, Dandenong, Victoria 3175, Australia \\ ${ }^{2}$ Wild Press, PO Box 12397, Wellington 6038, New Zealand \\ ${ }^{3}$ British Antarctic Survey, Natural Environment Research Council, Madingley Road, Cambridge CB3 0ET, United Kingdom \\ ${ }^{4} 17$ Ashmore Avenue, Pymble, New South Wales 2073, Australia \\ 559 Rocks Road, Nelson, New Zealand
}

\begin{abstract}
Three species of biennial breeding southern hemisphere albatrosses - Diomedea sanfordi from the Chatham Islands, D. antipodensis from Antipodes Island and D. exulans from South Georgia - were tracked using CLS-Argos satellite system during the 1990s. Harness attachment and duty cycling of transmitters enabled long-term deployments covering both the breeding and nonbreeding ranges. The feeding ranges for breeding birds of each species were different. D. sanfordi foraged over continental shelves to the shelf edge, whereas $D$. antipodensis and $D$. exulans ranged widely over deep water to the shelf edge. Mapping of satellite-determined locations for $D$. sanfordi and $D$. antipodensis showed that the demarcation was between the 1000 and 2000 m undersea contour. Non-breeding D. sanfordi wintered over the Patagonian shelf or over the Chilean shelf. There they were virtually confined to seas over the continental shelves of $<200 \mathrm{~m}$ depth, occasionally out to $<1000 \mathrm{~m}$ depth. Breeding D. exulans from South Georgia feeding chicks over the same period foraged pelagically and along steep continental slopes up to depths $>1000 \mathrm{~m}$, and on less steep slopes to $200 \mathrm{~m}$ depth. These data provide the best evidence yet of habitat preference and segregation consistent across breeding and non-breeding seasons for closely related seabirds.
\end{abstract}

KEY WORDS: Diomedea sp. · Great albatrosses · Satellite tracking $\cdot$ Foraging $\cdot$ Non-breeding birds · Breeding birds

Resale or republication not permitted without written consent of the publisher

\section{INTRODUCTION}

How seabirds exploit the different oceanic habitats when foraging is poorly known, particularly when they are not breeding. Satellite tracking and archival tags have shown that albatrosses and other Procellariiformes travel great distances to forage when breeding (Prince et al. 1992, 1998, Weimerskirch et al. 1993, 1999, Weimerskirch \& Robertson 1994, Nicholls et al. 1994, Walker et al. 1995, Freeman et al. 1997, Anderson et al. 1998, Brothers et al. 1998, Klomp \& Schultz 1999, Berrow et al. 2000, González-Solís et al. 2000a,b, Stahl \& Sagar 2000, Croxall \& Wood. 2001). They move even greater distances when non-breeding (Nicholls et al. 1995, 1998, 1999, 2000, Prince et al. 1998, Tuck et al.

*E-mail: d.nicholls@chisholm.vic.edu.au

${ }^{\mp}$ Deceased
1999, Ristow et al. 2000, Robertson \& Nicholls 2000, Stahl \& Sagar 2000, Weimerskirch \& Wilson 2000). Where 2 or more species can be tracked concurrently, it is possible to compare critically their behaviour (Wood et al. 2000) and determine whether they exploit similar or different habitat zones of the oceans they traverse. Such an opportunity arose with studies of the northern royal albatross Diomedea sanfordi, the Antipodean (wandering) albatross D. antipodensis and the wandering albatross $D$. exulans (Nicholls et al. 1996, 1999). This paper reports the consistently different use of shelf and shelf slope habitats by these species when foraging around the Chatham Islands, New Zealand, and off the Chilean and Argentinean coasts. It was also possible to compare the foraging behaviour of both breeding and non-breeding birds. All 3 taxa are biennial breeders with similar breeding cycles and timing. 


\section{MATERIALS AND METHODS}

The CLS-Argos tracking system was used. Satellite transmitters (platform transmitter terminals: PTTs) were from Telonics (Models ST6 and 10 with 2 AA cells) and Microwave Telemetry (Model NANNO with 2 AA cells) up to $140 \mathrm{~g}$ mass with attachment. The Antipodean (wandering) albatross and northern royal albatross were PTT tagged in New Zealand (Table 1). PTTs were glued with epoxy resin to the feathers

Table 1. Deployment details of satellite transmitters (platform transmitter terminals: PTTs) on Diomedea antipodensis, Antipodean (wandering) albatross (AWA); D. sanfordi, northern royal albatross (NRA); and D. exulans, wandering albatross (WAA) at New Zealand and off the east and west coasts of South America. BA: breeding aborted after deployment either during study period or subsequently; BR: nesting (incubating or brooding-feeding chick); F: female; FB: bird selected after having lost egg or chick; M: male; NB: adult bird bred the previous year and non-breeding at deployment; PB: young adult, courting but not yet breeding

\begin{tabular}{|c|c|c|c|c|c|c|c|c|}
\hline Bird & Species & Sex & PTT & No. locations & Start & Finish & No. days & Status \\
\hline \multicolumn{9}{|c|}{ Chatham Rise east of New Zealand, 10 February to 12 March 1996 between $170^{\circ} \mathrm{E}$ and $180^{\circ} \mathrm{W}$ and 41 and $46^{\circ} \mathrm{S}$} \\
\hline 1 & AWA & $\mathrm{F}$ & 21807 & 39 & 10 Feb 1996 & 17 Feb 1996 & 7.8 & $\mathrm{BR}$ \\
\hline 2 & AWA & $\mathrm{F}$ & 23082 & 14 & 10 Feb 1996 & 20 Feb 1996 & 10.3 & BA \\
\hline 3 & AWA & $\mathrm{F}$ & 23696 & 60 & 15 Feb 1996 & 27 Feb 1996 & 12.4 & $\mathrm{BR}$ \\
\hline 4 & AWA & $\mathrm{F}$ & 26590 & 2 & 10 Feb 1996 & 10 Feb 1996 & 0.1 & BA \\
\hline 5 & AWA & $\mathrm{F}$ & 26592 & 11 & 27 Feb 1996 & 7 Mar 1996 & 8.4 & FB \\
\hline 6 & AWA & $\mathrm{M}$ & 23080 & 35 & 10 Feb 1996 & 19 Feb 1996 & 9.7 & BA \\
\hline 7 & AWA & $\mathrm{M}$ & 23081 & 50 & 10 Feb 1996 & 19 Feb 1996 & 9.4 & BR \\
\hline \multirow[t]{2}{*}{8} & AWA & M & 23083 & 14 & 10 Feb 1996 & 13 Feb 1996 & 3.3 & BA \\
\hline & AWA & $\mathrm{M}$ & 23083 & 9 & 8 Mar 1996 & 12 Mar 1996 & 4.2 & BA \\
\hline 9 & AWA & $\mathrm{M}$ & 23695 & 168 & 10 Feb 1996 & 12 Mar 1996 & 31.1 & BA \\
\hline 10 & AWA & $\mathrm{M}$ & 26589 & 128 & 15 Feb 1996 & 11 Mar 1996 & 25.3 & BA \\
\hline 1 & NRA & $\mathrm{F}$ & 21316 & 154 & 12 Feb 1996 & 12 Mar 1996 & 29.0 & $\mathrm{BR}$ \\
\hline 2 & NRA & $\mathrm{F}$ & 21318 & 132 & 12 Feb 1996 & 12 Mar 1996 & 29.0 & $\mathrm{BR}$ \\
\hline 3 & NRA & M & 21317 & 100 & 12 Feb 1996 & 4 Mar $1996^{a}$ & 21.0 & $\mathrm{BR}$ \\
\hline 4 & NRA & $\mathrm{M}$ & 21320 & 138 & 12 Feb 1996 & 12 Mar 1996 & 29.0 & $\mathrm{BR}$ \\
\hline \multicolumn{9}{|c|}{ No. of AWA $=530$} \\
\hline \multicolumn{9}{|c|}{ No. of NRA $=524$} \\
\hline Total & 1054 & & & & & & & \\
\hline \multicolumn{9}{|c|}{ Patagonian shelf east of Argentina, 14 January to 24 October $1991-1998$, between 70 and $30^{\circ} \mathrm{W}$ and 34 and $61^{\circ} \mathrm{S}$} \\
\hline 1 & NRA & $\mathrm{F}$ & 21316 & 556 & 19 Mar 1996 & 30 Jun $1996^{\mathrm{b}}$ & 102.8 & FB \\
\hline \multirow[t]{2}{*}{2} & NRA & $\mathrm{F}$ & 26590 & 155 & 21 Feb 1997 & 2 Sep 1997 & 192.3 & FB \\
\hline & NRA & $\mathrm{F}$ & 26590 & 113 & 25 Feb 1998 & $5 \mathrm{Jul} 1998^{\mathrm{b}}$ & 129.3 & $\mathrm{FB}$ \\
\hline \multirow[t]{2}{*}{3} & NRA & $\mathrm{M}$ & 23738 & 119 & 15 Feb 1997 & 3 Aug 1997 & 168.3 & FB \\
\hline & NRA & $\mathrm{M}$ & 23738 & 207 & 14 Jan 1998 & 23 Jul 1998 & 189.3 & FB \\
\hline 4 & NRA & $\mathrm{F}$ & 06750 & 503 & 18 Apr 1998 & 24 Oct 1998 & 188.8 & PB \\
\hline 5 & NRA & $\mathrm{M}$ & 21805 & 118 & 9 Apr 1998 & 21 Aug 1998 & 134.5 & PB \\
\hline 1 & WAA & $\mathrm{F}$ & 1842 & 137 & 21 Apr 1996 & 5 Мау 1996 & 13.7 & $\mathrm{BR}$ \\
\hline 2 & WAA & $\mathrm{F}$ & 9286 & 117 & 4 Apr 1991 & 13 Apr 1991 & 8.6 & $\mathrm{BR}$ \\
\hline 3 & WAA & $\mathrm{F}$ & 9287 & 215 & 26 Jun 1991 & 14 Jul 1991 & 18.2 & $\mathrm{BR}$ \\
\hline 4 & WAA & $\mathrm{M}$ & 9131 & 75 & 24 Jun 1991 & 6 Jul 1991 & 12.2 & $\mathrm{BR}$ \\
\hline 5 & WAA & $\mathrm{M}$ & 9131 & 165 & 27 Apr 1996 & 9 May 1996 & 11.8 & $\mathrm{BR}$ \\
\hline 6 & WAA & $\mathrm{M}$ & 9288 & 196 & 6 Jul 1991 & 23 Jul 1991 & 17.3 & $\mathrm{BR}$ \\
\hline 7 & WAA & $\mathrm{M}$ & 9296 & 212 & 29 Jun 1991 & 14 Jul 1991 & 15.1 & $\mathrm{BR}$ \\
\hline 8 & WAA & $\mathrm{M}$ & 9297 & 232 & 14 Apr 1991 & 1 May 1991 & 17.1 & $\mathrm{BR}$ \\
\hline \multicolumn{9}{|c|}{ No. of NRA $=1759$} \\
\hline \multicolumn{9}{|c|}{ No. of WAA = 1349} \\
\hline Total & 3108 & & & & & & & \\
\hline \multicolumn{9}{|c|}{$\begin{array}{l}\text { Chile, } 13 \text { February to } 10 \text { September during } 1996 \text { and } 1998 \text {, between } 90 \text { and } 70^{\circ} \mathrm{W} \text { and } 39 \text { and } 52^{\circ} \mathrm{S} \\
\text { (including occasional extensive looping flights into the SE Pacific Ocean beyond the study area) }\end{array}$} \\
\hline 1 & AWA & $\mathrm{M}$ & 26591 & 96 & 13 Feb 1996 & 24 Apr 1996 & 71.0 & NB \\
\hline 2 & AWA & $\mathrm{M}$ & 23083 & 129 & 1 Apr 1996 & 27 Apr $1996^{b}$ & 26.0 & BA \\
\hline 1 & NRA & $\mathrm{M}$ & 26593 & 618 & 24 Feb 1998 & 10 Sep 1998 & 197.7 & NB \\
\hline \multicolumn{9}{|c|}{ No. of AWA $=225$} \\
\hline \multicolumn{9}{|c|}{ No. of NRA $=618$} \\
\hline Total & 843 & & & & & & & \\
\hline${ }^{\mathrm{a}}$ Lost & t at sea & & & & & & & \\
\hline
\end{tabular}


Table 2. Comparison of the distribution of Diomedea sanfordi, northern royal albatross (NRA), with coexisting D. exulans, wandering albatross (WAA), or D. antipodensis, antipodean (wandering) albatross (AWA), in 3 oceanic habitats at 3 regions: east of New Zealand, and east and west of southern South America. Data are from one (the first) satellite-determined location per day (FLD). -: included in $<1000 \mathrm{~m}$ category

\begin{tabular}{|c|c|c|c|c|c|c|c|}
\hline \multirow[t]{2}{*}{ Region } & \multirow[t]{2}{*}{ Species } & \multicolumn{2}{|c|}{ No. of } & \multirow[b]{2}{*}{$\begin{array}{c}\text { Inner } \\
\text { shelf }\end{array}$} & \multicolumn{2}{|c|}{ Percentages in habitats } & \multirow[b]{2}{*}{$\begin{array}{l}\text { Pelagic } \\
\& \text { slope }\end{array}$} \\
\hline & & Birds & FLDs & & $\begin{array}{l}\text { Outer } \\
\text { shelf }\end{array}$ & $\begin{array}{l}\text { Shelf break- } \\
\text { upper slope }\end{array}$ & \\
\hline Depth (m) & & & & $<200$ & $<1000$ & $<2000$ & $>2000$ \\
\hline Chatham Rise, & NRA & 4 & 112 & - & 77.7 & 16.1 & 6.2 \\
\hline SW Pacific Ocean & AWA & 10 & 101 & - & 15.8 & 31.7 & 52.5 \\
\hline Patagonian shelf, & NRA & 5 & 490 & 84.5 & 12.9 & 2.6 & 0.0 \\
\hline SW Atlantic Ocean. & WAA & 8 & 122 & 18.8 & 32.0 & 6.6 & 42.6 \\
\hline Humboldt Current, & NRA & 1 & 177 & 22.6 & 29.9 & 23.2 & 24.3 \\
\hline SE Pacific Ocean & AWA & 2 & 56 & 0.0 & 0.0 & 1.8 & 98.2 \\
\hline
\end{tabular}

(Nicholls et al. 1995) of 4 northern royal albatrosses on the Sisters Islands, Chatham Islands in 1996. In order to obtain flight data for a year or more, the PTTs were attached by harnesses designed for Antipodean (wandering) albatross (K. Walker, G. Elliott unpubl.) and for subsequent northern royal albatross (C. Robertson unpubl.). Transmission regimens for the PTTs have been tested over several years, and progressively longer duty cycles and slower repetition rates have extended the potential transmission life to beyond $3 \mathrm{yr}$. This provides a reduced number of locations per unit time, but sufficient to give unambiguous locations (Britten et al. 1999). For wandering albatrosses from Bird Island, South Georgia (Prince et al. 1992, 1998), PTTs were glued to the feathers, and these were generally removed after a single foraging trip. They transmitted on a continuous duty cycle.

The CLS-Argos system classifies the locations and estimates their accuracy. Approximately $24 \%$ of our locations had an error of $<1 \mathrm{~km}$ standard deviation (Classes 3 to 1 ), but the accuracy of the rest was unspecified (Classes 0 to Z) (Anon 1996). Using the archival CLS-Argos DIAG files, great circle distance and point-to-point ground speed to each location were calculated. The locations associated with a speed $>120 \mathrm{~km} \mathrm{~h}^{-1}$ and locations over land were excluded. All locations, especially those associated with a speed $>60 \mathrm{~km} \mathrm{~h}^{-1}$, were inspected. Those with a speed $>100 \%$ from that of the highest adjacent locations and of poor class accuracy and those of very poor class accuracy were excluded. This process was repeated. In the final data there were no speeds over $100 \mathrm{~km} \mathrm{~h}^{-1}$. The accuracy of locations of the retained Classes 0 to $Z$ is about 10 to $20 \mathrm{~km}$. (D. Nicholls, C. Robertson unpubl.). All the retained locations were included in the figures and Table 1; however, for the statistical comparisons only the first location for the day was used to reduce serial auto- correlation, and it is these values that are reported in Table 2.

The taxonomic nomenclature is based on Nunn et al. (1996), Robertson \& Nunn (1998) and Croxall \& Gales (1998), except in the discussion on the diet, where the names used are those in the papers quoted.

Within the New Zealand region, data were available from the concurrent tracking of breeding birds, between 10 February and 12 March 1996. Foraging behaviour was compared in an area bounded by 41 and $46^{\circ} \mathrm{S}$ and between $175^{\circ} \mathrm{E}$ and $170^{\circ} \mathrm{W}$ (Fig. 1). There were 2 breeding pairs ( 4 northern royal albatrosses),

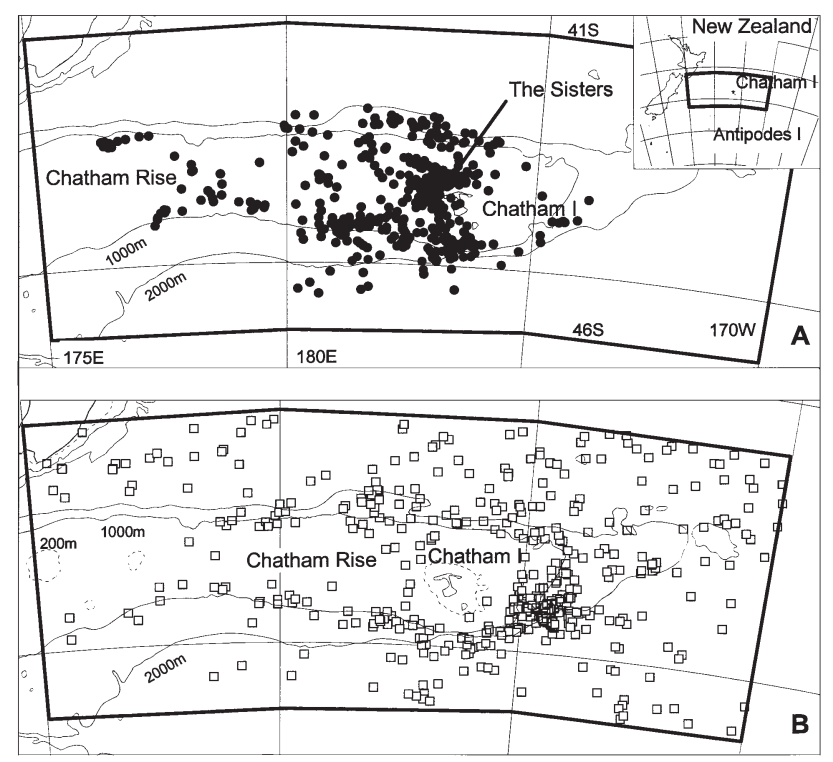

Fig. 1. Distribution of 2 taxa of Diomedea albatross. (A) Northern royal albatross $(\bullet)$ in the Chatham Rise region, east of the New Zealand mainland, and (B) Antipodean (wandering) albatross (ם). The rectangle encloses the study area; see 'Materials and methods'. The 200, 1000 and $2000 \mathrm{~m}$ isobaths are shown 


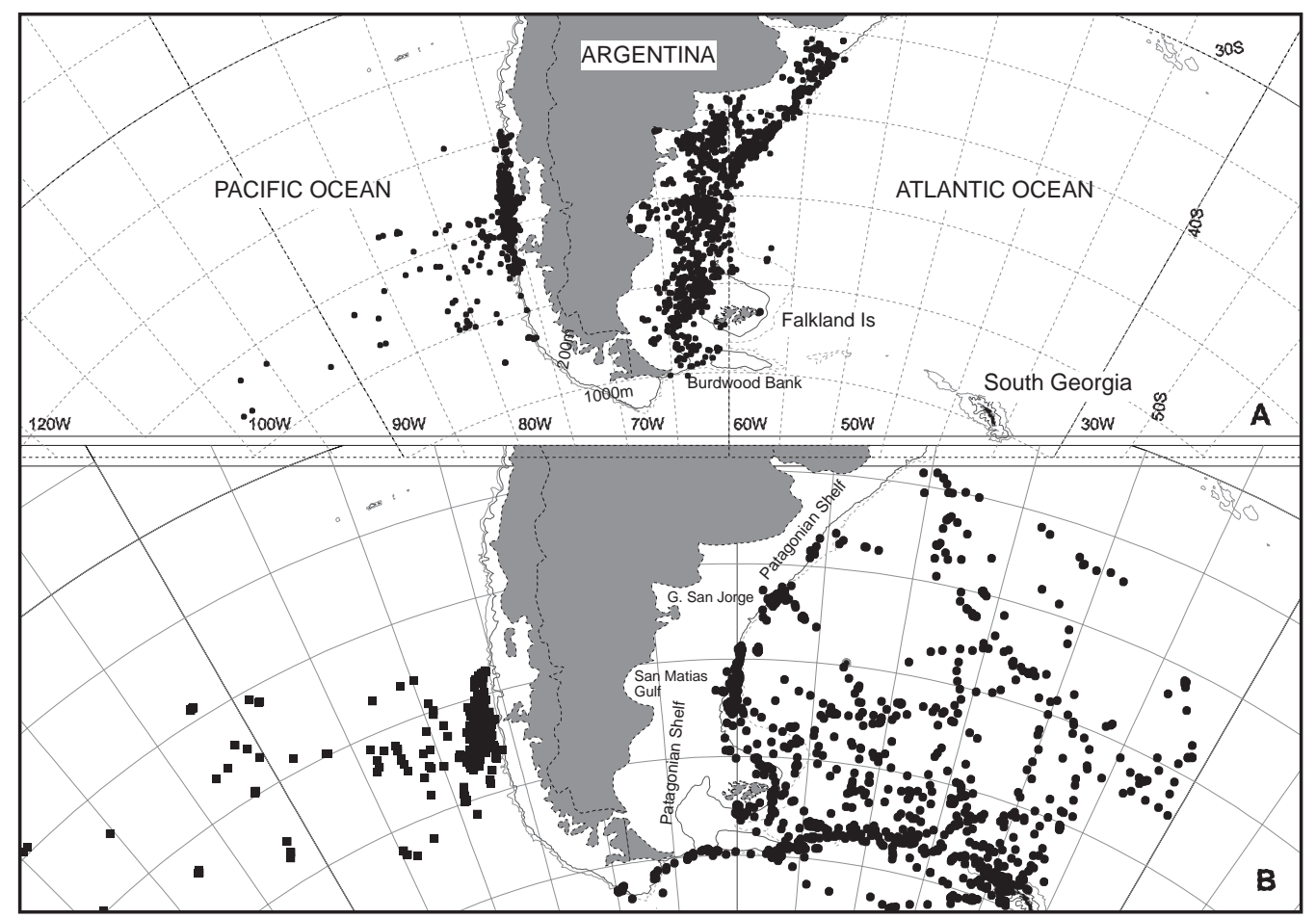

Fig. 2. Distribution of 3 taxa of Diomedea albatross off South America. (A) Northern royal albatross (•) in the Pacific and Atlantic Oceans; (B) Antipodean (wandering) albatross (घ) in the Pacific Ocean and wandering albatross (•) in the Atlantic Ocean. The 200 and $1000 \mathrm{~m}$ isobaths are shown

compared with 5 female and 5 male Antipodean (wandering) albatrosses. At this time northern royal albatross adults were guarding chicks throughout the period, whereas Antipodean (wandering) albatross adults were incubating eggs. The first 3 Antipodean (wandering) albatrosses flew from the breeding island directly to this study area, but the other 7 individuals foraged in and beyond the prescribed area. Not all returned to their nests during and after this period so their breeding status changed during the period. Flights outside this study area (which form part of other studies) will be reported elsewhere.

In the south Atlantic Ocean and Patagonian shelf region, there were 7 visits by 5 northern royal Albatross, 2 males and 3 females, tracked there for periods from February to September, between 1996 and 1998. One of these birds was a failed breeder (it apparently lost its mate), and 2 were tracked over consecutive years and were originally chosen because they had failed breeding before deployment; they did not breed successfully in the next year. Two were young adults that had not previously bred. Wandering albatross data from South Georgia for the same months of the year comprised 4 males and 2 females from April and July 1991, and 1 female and 1 male in April 1996. Thus, the northern royal albatrosses were non-breeders or failed breeders at the time, whereas the wandering albatross adults were feeding chicks. The study area for a comparison of the foraging behaviour (i.e. excluding the locations during migration) was from between 70 and $30^{\circ} \mathrm{W}$ and between 34 and $61^{\circ} \mathrm{S}$ (Fig. 2).

Data from Chile and the southeast Pacific Ocean region included 1 northern royal albatross male from Taiaroa Head, New Zealand in 1998 and 2 Antipodean (wandering) albatross males, tracked in 1996. The northern royal albatross had abandoned incubation of a failed egg prior to the deployment. Of the 2 Antipodean (wandering) albatrosses, 1 had successfully raised a chick in 1995-96, and the other had abandoned its incubation in 1996 during the initial weeks of the January deployment and before flying to Chile, arriving 1 April 1996. The study area off Chile was between 90 and $70^{\circ} \mathrm{W}$ and between 39 and $52^{\circ} \mathrm{S}$ (Fig. 2). All 3 birds flew rapidly and directly to Chile. The northern royal albatrosses and 1 of the Antipodean (wandering) albatross returned to Australasian seas, but contact was lost with the second Antipodean (wandering) albatross at the time its battery was expected to have become exhausted.

The bathymetry was from GEBCO 97 Digital Atlas (IOC, IHO 1997). For all 3 study areas, 3 categories of water depth were used: 0 to $1000 \mathrm{~m}$, shelf; 1000 to $2000 \mathrm{~m}$, shelf break and slope; and >2000 m, lowest slope and abyssal sea floor. The Patagonian and 
Chilean shelves were further subdivided into 0 to 200 and 200 to $1000 \mathrm{~m}$ regions (Table 2).

\section{RESULTS}

\section{South west Pacific Ocean — Chatham Rise}

The northern royal albatrosses, breeding at the Sisters Islands $\left(43^{\circ} \mathrm{S}, 177^{\circ} \mathrm{W}\right)$, foraged over the shallow waters of the Chatham Rise out to the shelf slope between 1500 and $2000 \mathrm{~m}$ water depth (Fig. 1A). Whereas all northern royal albatross data obtained were within the defined study area, the Antipodean (wandering) albatrosses, which breed at Antipodes Island $\left(50^{\circ} \mathrm{S} 178^{\circ} \mathrm{E}\right)$, had an extensive range outside this area (D. Nicholls, K. Walker, G. Elliott unpubl.). Within the study area, the Antipodean (wandering) albatrosses generally foraged over water deeper than $1000 \mathrm{~m}$ (Fig. 1B). The few locations on the shelf were along the paths of tracked direct flights across the shelf. Of 112 northern royal albatross observations, 94\% were over the shelf or shelf slope, whereas $82 \%$ of 101 Antipodean (wandering) albatross observations were pelagic or over the deeper shelf slope (Table 2). Both species were concentrated over the steepest shelf slopes at the south and east of the Chatham Rise, where there were rapid changes in depth and direction of the slope. These, particularly in the east of the Rise, were likely to be areas of marine upwelling. The distribution of the 2 species overlapped by 25 to $75 \mathrm{~km}$, typically at the shelf break, a narrow overlap given the extent of their respective ranges.

\section{South Atlantic Ocean - Patagonian shelf}

Failed-breeding and non-breeding northern royal albatross adults from the Sisters Islands and Taiaroa Head $\left(46^{\circ} \mathrm{S}, 171^{\circ} \mathrm{E}\right)$ were tracked from 1996 to 1998 in the southwest Atlantic Ocean (Fig. 2A). They arrived from the Pacific Ocean around Cape Horn and flew directly to the Patagonian shelf, off Argentina, where they remained between 14 January and 2 September (Robertson \& Nicholls 2000). Their distribution was compared with those of breeding wandering albatrosses from South Georgia, between April and July, when the latter were rearing chicks. The general pattern of distribution was the same each year: northern royal albatross always preferred the shelf and wandering albatross always preferred deep water. Between years, however, there was some variation in the distributions amongst oceanic habitats, especially in the
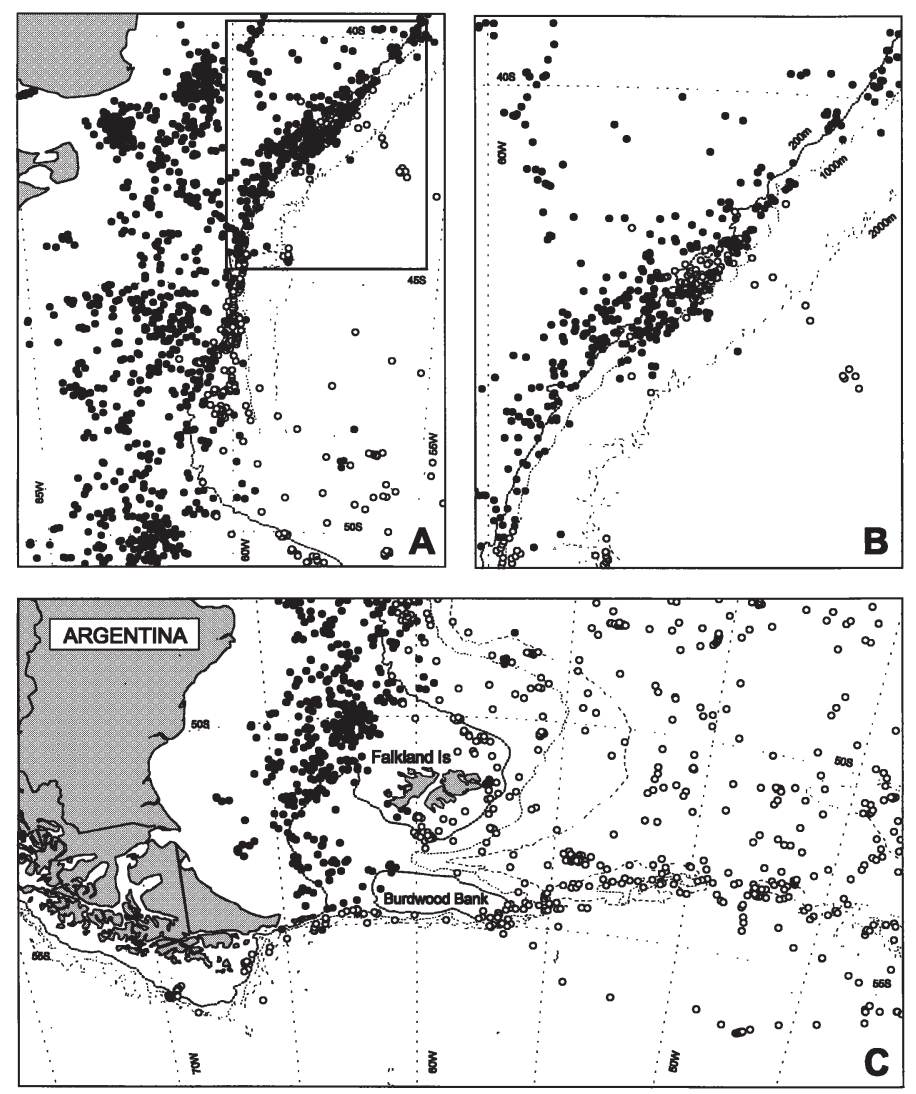

Fig. 3. Overlapping distribution of northern royal $(\bullet)$ and wandering albatross (O) (A) in the northern regions of the Patagonian shelf between 40 and $50^{\circ} \mathrm{S}$ (rectangle marking enlarged area), (B) between 40 and $44^{\circ} \mathrm{S}$ and (C) in the Falkland Island-Burdwood Bank region of the Patagonian shelf. The 200, 1000 and $2000 \mathrm{~m}$ isobaths are shown

dynamic seas over the shelf edge for the northern royal albatross $\left(\chi^{2}=31.654\right.$, df $\left.=4, \mathrm{p}=0.000\right)$ but not the wandering albatross $\left(\chi^{2}=2.049, \mathrm{df}=3, \mathrm{p}=0.562\right)$.

The northern royal albatrosses foraged over the Patagonian shelf from its southern edge to $35^{\circ} \mathrm{S}$ in the north (Fig. 2A). All 1759 locations were between 30 and $400 \mathrm{~km}$ from the South American coast in the north (latitude $30^{\circ} \mathrm{S}$ ) and between 30 and $600 \mathrm{~km}$ in the south (latitude $\left.55^{\circ} \mathrm{S}\right)$. They were widespread over waters $<200 \mathrm{~m}$ in depth, but flights extended to, and over, the shelf break to $1000 \mathrm{~m}$ depth between latitudes 36 and $49^{\circ} \mathrm{S}$ (Figs. 2A \& 3A). The locations extended further beyond the shelf break along $100 \mathrm{~km}$ of the steepest portion of the shelf slope, between 41.5 and $42.5^{\circ} \mathrm{S}$ (Fig. 3A). Further south near the Falkland Islands, the flights were confined to the shelf, west of the islands (Fig. 3C), and did not approach the deeper shelf slope. On 21 April 1998,4 locations were off the shelf at $48^{\circ} \mathrm{S}, 57^{\circ} \mathrm{W}$ over pelagic waters (Fig. 3C). The inshore flights by 3 individuals in the Gulf of San Jorge and San Matias Gulf were exceptional, as only 26 of 1759 (1.5\%) locations 


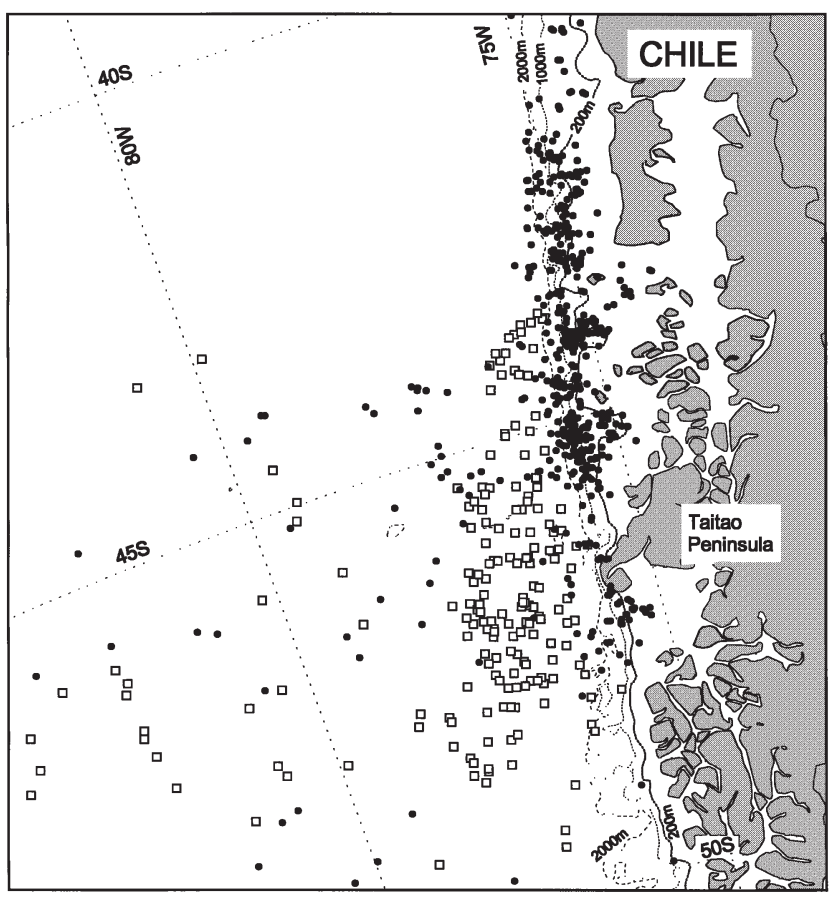

Fig. 4. Abutting distribution of the northern royal $(\bullet)$ and Antipodean (wandering) albatross () off the Chilean coast between 40 and $50^{\circ} \mathrm{S}$. The 200, 1000 and $2000 \mathrm{~m}$ isobaths are shown

were within $30 \mathrm{~km}$ of the coast (Fig. 2A). There were no locations within $30 \mathrm{~km}$ of the Falkland Islands coast, except 10 locations from 2 birds as they first flew past onto the shelf (Fig. 3C).

The wandering albatross locations were widespread over the southwest Atlantic Ocean to the north and west of the breeding colony at Bird Island, South Georgia (Fig. 2B). East of $50^{\circ} \mathrm{W}$, the locations were over pelagic waters. Many of the flights were towards and along the continental shelf edge of South America. The birds did not fly over the shelf (Fig. 3), except in the southern seas to the east of the Falkland Islands (Fig. 3C), where there were concentrations along the very steep shelf edge of the Patagonian shelf north of $48^{\circ} \mathrm{S}$ and at the Burdwood Bank east of Cape Horn at $50^{\circ} \mathrm{S}$. Locations were almost entirely in waters $>1000 \mathrm{~m}$ depth, except at the steepest shelf slopes, where a few were over shallower waters to an estimated depth of $500 \mathrm{~m}$.

The distributions of the northern royal albatrosses, in 3 oceanic habitats, were compared with either the Antipodean (wandering) or the wandering albatrosses (Fig. 2). In the south Atlantic Ocean both species flew to the continental shelf slope, the royals eastwards from the Patagonian shelf and the wanderers westwards from the open ocean. Both species were present over the narrow width of seas with depths between 200 and ca. $1250 \mathrm{~m}$, where the shelf slope was very steep, and between 200 and $<500 \mathrm{~m}$, where the slope was much less steep. The steep slopes were extensive and generally north of $47.5^{\circ} \mathrm{S}$. Less steep slopes were confined to between 47.5 and $50^{\circ} \mathrm{S}$. The width of overlap of the 2 species ranged from the narrowest of $55 \mathrm{~km}$ in the north to $100 \mathrm{~km}$ at the widest at $49^{\circ} \mathrm{S}$. However, this overlap was recorded from different years. Around the Falkland Islands, there were only locations of northern royal albatross flying past the islands and the 2 species did not overlap. The wandering albatross locations were over the outer shelf around the Falkland Islands where the slope was broad and beyond 15 to $30 \mathrm{~km}$ distant from the islands.

After a pelagic migration, between New Zealand and Argentinian continental shelves, the northern royal albatrosses remained on the continental shelf until they abruptly departed, and the wandering albatrosses were generally pelagic (see above). Their use of habitats is further compared using one location per day (the first observation) (Table 2). Approximately $84 \%$ of 490 observations were on the shelf, over seas $<200 \mathrm{~m}$ depth, 97\% were over shelf seas <1000 m deep (Table 2), and more than 99\% were either over seas $<1000 \mathrm{~m}$ depth, or within $25 \mathrm{~km}$ of this isobath (Figs. 2 \& 3). In contrast, the wandering albatrosses were pelagic, with $43 \%$ of 122 observations over water depths of more than $2000 \mathrm{~m}$ and $7 \%$ over the outer edge of the shelf along the $1000 \mathrm{~m}$ isobath. A further $32 \%$ took place over $>200 \mathrm{~m}$ depth, mostly where the slope was least steep around the Falkland Islands or over the Burdwood Bank or around South Georgia. Fewer than 19\% were over the Patagonian shelf at depths of between 0 and $200 \mathrm{~m}$, and these were only around the Cape Horn (including the Burdwood Bank), Falkland Islands or South Georgian shelves (Table 2).

\section{Chilean shelf and Humboldt Current}

The continental shelf off western Chile is very narrow and the shelf slope extremely steep compared with the other 2 areas considered. The locations of the single northern royal albatross were at the outer portion of the shelf and over the slope between 39 and $48^{\circ} \mathrm{S}$, between February and September 1998 (Figs. 2A \& 4). The easterly limit of the distribution closely followed the bathymetry along the $200 \mathrm{~m}$ isobath, 35 to $45 \mathrm{~km}$ offshore, but extended into shallower water in embayments. Off the Taitao Peninsula, where there were minimal shelf and the steepest shelf slope, there were 13 locations within $15 \mathrm{~km}$ and 3 within $1 \mathrm{~km}$ of the shore. On the seaward limit of the shelf distribution, there were 2 pelagic excursions into the Pacific Ocean between 21 and 26 May 1998 to $105^{\circ} \mathrm{W}$, ranging out 
$2475 \mathrm{~km}$, and again between 12 and 21 September 1998 to $113^{\circ} \mathrm{W}$ (Fig. 4). These flights off the shelf were in contrast to the behaviour of northern royal albatrosses in Patagonian seas, where the species rarely left the shelf.

Two Antipodean (wandering) albatrosses were pelagic between $110^{\circ}$ and $70^{\circ} \mathrm{W}$ during February to April 1996 (Fig. 2). They did not venture over waters $<1000 \mathrm{~m}$ depth, nor did they come closer than $65 \mathrm{~km}$ to the shore except for $16(7.1 \%)$ of 225 locations, of which 13 were near Taitao Peninsula, the closest at $26 \mathrm{~km}$ (Fig. 4). Like the northern royal albatross, these birds made excursions out into the seas of abyssal depths; one bird made 3 flights ranging out $1750 \mathrm{~km}$ between 12 March and 21 April, and the other made a single flight out $780 \mathrm{~km}$ between 9 and 12 April.

The 2 species are compared in their use of habitat (Table 2) using the single observation per day data. The 2 Antipodean (wandering) albatrosses were pelagic ( $98 \%$ of 56 observations), contrasted with the single northern royal albatross that was over the shelf or shelf break (76\% of 177 observations).

In all 3 regions there was a significant association between species and oceanic habitat (Table 2; Chatham Rise New Zealand $\chi^{2}=87.8, \mathrm{df}=2, \mathrm{p}=0.000$; Chile $\chi^{2}=95.4, \mathrm{df}=1, \mathrm{p}=0.000$; Patagonian shelf $\chi^{2}=$ 203.2, $\mathrm{df}=1, \mathrm{p}=0.000)$.

\section{DISCUSSION}

The distribution patterns of foraging northern royal albatross and one of either Antipodean (wandering) albatross or the wandering albatross were similar at 3 oceanic regions: the Chatham Rise east of New Zealand; off Chile; and the Patagonian shelf and Burdwood Bank (Figs. 1 \& 2, Table 2). The northern royal albatross migrates very rapidly between these continental shelves (Robertson \& Nicholls 2000), where they remain to forage. The Antipodean (wandering) albatross and wandering albatross were pelagic over abyssal oceans and over the deepest shelf slopes, but were mutually exclusive, separating themselves spatially off the South American shelves. These patterns, for both breeding and non-breeding adults, remained constant for long periods of the year and were similar between different years. This is the first time nonbreeding and breeding foraging distributions for 3 closely related Procellarriiforme congeners have been recorded and compared.

The Patagonian shelf, especially the central and southern portions, is extensive and stretches $500 \mathrm{~km}$ offshore (Figs. 2 \& 3). Northern royal albatrosses remained in this area for many months. Their greatest abundance was mid-way between the coast and the shelf break, 200 to $350 \mathrm{~km}$ offshore in the widest sections of the shelf, over waters $<200 \mathrm{~m}$ depth (Fig. 2A). Generally, birds foraged on the shelf, more than $30 \mathrm{~km}$ from land including the Falkland Islands. On the narrow Chilean shelf, they were also a similar distance off shore, which put them over both the outer shelf and upper shelf slope. On the Chatham Rise (Fig. 1), however, the distribution was broadly similar to a shelf distribution, with reduced numbers close to the main Chatham Islands, but an additional concentration of birds close to the breeding colony and short flights off the shelf. Imber (1999) described the royal albatross as 'king of the shelf break and inner slope', but our observations indicate that the northern royal albatross is primarily a bird of the shelf with a distribution extending to and including the shelf break and inner (upper) slope.

The wandering albatross flew throughout the year over abyssal waters or the deep lower slope of the shelf (Weimerskirch et al. 1988). However, they did fly over the outer shelf (over water $>200 \mathrm{~m}$ depth) near the Falkland Islands (this paper, Croxall et al. 1999, White et al. 1999), as they do regularly around the southern coast of Australia (Wood 1992, Battam \& Smith 1993, Nicholls et al. 1995). Two Antipodean (wandering) albatrosses approached the lower shelf slope from the ocean and occasionally flew directly over the shelf of the Chatham Rise. A breeding bird that aborted incubation after deployment and a non-breeding adult migrated across the Pacific Ocean to Chilean waters, where they behaved similarly, not venturing over the narrow shelf. All 3 species, while feeding in relatively confined areas either over the shelf, the shelf break or the lower slope, made occasional extensive looping flights over abyssal waters and back to the previous foraging area. Non-breeding Diomedea exulans and D. gibsoni make similar flights off the eastern Australian coast (Nicholls et al. 2000).

At all places, there are local variations in abundance due to ecological factors including the extent of the shelf, nature of the bathymetry, oceanic currents, productivity and anthropogenic effects, each of which influence the availability of albatross prey (see review by Schneider 1997). Of these effects, the prey of the albatross is probably the most directly influential (aside from the breeding island). The diet is known from samples obtained at the breeding islands (almost entirely from breeding birds and including those feeding chicks); the diet at other times is almost unknown. Squid and fish are the major items in the diet, but the fish component is under-represented (Cherel \& Klages 1998), so only the cephalopod portion is discussed here.

Presumably a major mechanism in the resource partitioning between the great albatrosses described in 
this paper is their consumption of different prey items. Northern royal albatross feed on Moroteuthopsis (= Moroteuthis) ingens, Pinnoctopus (Octopus) cordiformi, Histioteuthis atlantica and Nototodarus spp. (Imber 1999). By contrast, wandering albatross (this includes both the wandering albatross and Antipodes [wandering] albatross) feed principally on 7 species including histioteuthids at lowest latitudes, several onychoteuthids, particularly Kondakovia longimana at higher latitudes, M. knipovitchi at Antipodes Island and $M$. ingens. Only $M$. ingens, a widespread cephalopod that also occurs on the Patagonian shelf (Imber 1999, Xavier et al. 1999), is regularly in the diets of all 3 species (Imber 1992, Cherel \& Klages 1998). These differences suggest that breeding birds exploit different food resources except when both are feeding over the shelf, when $M$. ingens is taken extensively by wandering albatross during short foraging trips (Cherel \& Weimerskirch 1999). The northern royal albatross breeding and non-breeding birds had similar foraging behaviour, but the non-breeding birds may have a different diet, for as yet there is no information on their diet when foraging in South American seas.

Northern royal albatross and wandering albatross exploit different marine habitats and food resources. The northern royal albatross exploits those of the shelf and shelf edge, and the wandering albatross and the related Antipodean (wandering) albatross exploit those of the pelagic ocean, the shelf break and occasionally the shelf. The northern royal albatross generally only uses the pelagic oceans to commute between shelf foraging sites.

Acknowledgements. Funds were provided by the Australian Research Council, Ian Potter Foundation, W. V. Scott Estate, World Wide Fund for Nature Australia and Department of Conservation New Zealand. Support was provided by La Trobe University, Chisholm Institute and Department of Conservation, New Zealand. Graham Robertson, Australian Antarctic Division, made available satellite transmitters at short notice. David Bell and Mike Bell made great efforts at The Sisters to recover the transmitters. Approval for the work was provided by Animal Ethics NSW Director-General Committee and the Animal Ethics Committee of Department of Conservation Wellington, New Zealand. Access and research permits were provided by the New Zealand Department of Conservation, and approval to land on the Sisters Islands was given by its private owners. Mike Imber helped with the discussion of the diet. We are grateful to John Croxall and Andy Wood of the British Antarctic Survey for the wandering albatross data from the South Atlantic Ocean, and John Croxall and 4 anonymous referees for advice and comments on earlier drafts of this paper.

\section{LITERATURE CITED}

Anderson DJ, Schwandt AJ, Douglas HD (1998) Foraging ranges of Waved albatrosses in the eastern Tropical Pacific
Ocean. In: Robertson G, Gales R (eds) albatross biology and conservation. Surrey Beatty \& Sons, Chipping Norton, p 180-185

Anon (1996) Argos user's manual. CLS-Argos, Landover

Battam H, Smith LE (1993) Report on review and analysis of: albatross banding data held by the Australian Bird and Bat Banding Schemes-other relevant data. Australian National Parks and Wildlife Service Research and Surveys Consultancy Agreement No. 138, Canberra, p 165

Berrow SD, Wood A, Prince PA (2000) Foraging location and range of white-chinned petrels Procellaria aequinoctialis breeding in the South Atlantic. J Avian Biol 31:303-311

Britten MW, Kennedy PL, Ambrose S (1999) Performance and accuracy evaluation of small satellite transmitters. J Wildl Manage 64:1349-1358

Brothers N, Gales R, Hedd A, Robertson G (1998) Foraging movements of the Shy albatross Diomedea cauta breeding in Australia; implications for interaction with longline fisheries. Ibis 140:446-457

Cherel Y, Klages N (1998) A review of the food of albatrosses. In: Robertson G, Gales R (eds) albatross biology and conservation. Surrey Beatty \& Sons, Chipping Norton, p 113-136

Cherel Y, Weimerskirch H (1999) Spawning cycle of onychoteuthid squids in the southern Indian Ocean: new information from seabird predators. Mar Ecol Prog Ser 188:93-104

Croxall JP, Gales R (1998) An assessment of the conservation status of albatrosses. In: Robertson G, Gales R (eds) albatross biology and conservation. Surrey Beatty \& Sons, Chipping Norton, p 46-65

Croxall JP, Wood AG (2002) The importance of the Patagonian Shelf to top predator species breeding at South Georgia. Aquat Conserv (in press)

Croxall JP, Black AD, Wood AG (1999) Age, sex and status of wandering albatrosses Diomedea exulans L. in Falkland Islands waters. Antarct Sci 11:150-156

Freeman AND, Nicholls DG, Wilson KJ, Bartle JA (1997) Radio- and satellite tracking Westland Petrels Procellaria westlandica. Mar Ornithol 25:31-36

González-Solís J, Croxall JP, Wood AG (2000a) Sexual dimorphism and sexual segregation in foraging strategies of northern giant petrels Macronectes halli during the incubation period. Oikos 90:390-398

González-Solís J, Croxall JP, Wood AG (2000b) Foraging partitioning between giant petrels Marconectes spp and its relationship with breeding changes at Bird Island, South Georgia. Mar Ecol Prog Ser 204:279-288

Imber MJ (1992) Cephalopods eaten by wandering albatrosses Diomedea exulans breeding at six circumpolar localities. J R Soc NZ 22:243-263

Imber MJ (1999) Diet and feeding ecology of the royal albatross Diomedea epomophora - king of the shelf break and inner slope. Emu 99:200-211

IOC (Intergovernmental Oceanographic Commission), IHO (International Hydrographic Organization) (1997) GEBCO 97 digital atlas. British Oceanographic Data Centre, Birkenhead (CD-ROM)

Klomp NI, Schultz MA (1999) The remarkable foraging behaviour of Short-tailed Shearwaters breeding in eastern Australia. In: Adams NJ, Slotow RH (eds) Proceedings of the 22nd International Ornithological Congress, Durban. Ostrich 69:373

Nicholls DG, Murray MD, Robertson CJR (1994) Oceanic flights of the northern royal albatross Diomedea epomophora sanfordi using satellite telemetry. Corella 18: $50-52$ 
Nicholls DG, Murray MD, Battam H, Robertson G, Moors PJ, Butcher E, Hildebrandt M (1995) Satellite tracking of the wandering albatross Diomedea exulans around Australia and in the Indian Ocean. Emu 95:223-230

Nicholls DG, Murray MD, Elliott GP, Walker KJ (1996) Satellite tracking of a wandering albatross from the Antipodes Islands to South America. Corella 20:28

Nicholls DG, Stampton P, Klomp NI, Schultz M (1998) Postbreeding flight to the Antarctic waters by a Short-tailed Shearwater Puffinus tenuirostris. Emu 98:79-81

Nicholls DG, Robertson CJR, Prince PA, Murray MD, Walker KJ, Elliott GP (1999) Behavioural evidence for oceanic feeding range niches among three Diomedea albatrosses. In: Adams NJ, Slotow RH (eds) Proceedings of the 22nd International Ornithological Congress, Durban. Ostrich 69:203

Nicholls DG, Murray MD, Butcher EC, Moors PJ (2000) Time spent in Southern Ocean Exclusive Economic Zones by non-breeding wandering albatrosses (Diomedea spp.): implications for national responsibilities for conservation. Emu 100:318-323

Nunn GB, Cooper J, Jouventin P, Robertson CJR, Robertson GG (1996) Evolutionary relationships among extant albatrosses (Procellariiformes: Diomedeidae) established from complete cytochrome- $b$ gene sequences. Auk 113:784-801

Prince PA, Wood AG, Barton T, Croxall JP (1992) Satellite tracking of wandering albatrosses (Diomedea exulans) in the South Atlantic. Antarct Sci 4:31-36

Prince PA, Croxall JP, Trathan PN, Wood AG (1998) The pelagic distribution of South Georgia albatrosses and their relationships with fisheries. In: Robertson G, Gales R (eds) albatross biology and conservation. Surrey Beatty \& Sons, Chipping Norton, p 137-167

Ristow D, Berthold P, Hashmi D, Querner U (2000) Satellite tracking of Cory's Shearwater migration. Condor 102: 696-699

Robertson CJR, Nicholls DG (2000) Round the world with the northern royal Albatross. Notornis 47:176

Robertson CJR, Nunn GB (1998) Towards a new taxonomy for albatrosses. In: Robertson G, Gales R (eds) albatross biology and conservation. Surrey Beatty \& Sons, Chipping Norton, p 13-19

Schneider D (1997) Habitat selection by marine birds in relation to water depth. Ibis 139:175-178

Editorial responsibility: Otto Kinne (Editor), Oldendorf/Luhe, Germany
Stahl JC, Sagar PM (2000) Foraging strategies and migration of southern Buller's albatross Diomedea $b$. bulleri breeding on the Solander Is, New Zealand. J R Soc NZ 30: 319-334

Tuck GN, Polacheck T, Croxall JP, Weimerskirch H, Prince PA, Wotherspoon S (1999) The potential of archival tags to provide long-term movement and behaviour data for seabirds: first results from wandering albatross Diomedea exulans of South Georgia and the Crozet Islands. Emu 99: $60-68$

Walker KJ, Elliott G, Nicholls D, Murray D, Dilks P (1995) Satellite tracking of wandering albatross (Diomedea exulans) from the Auckland Islands: preliminary results. Notornis 42:127-137

Weimerskirch H, Robertson G (1994) Satellite tracking of light-mantled sooty albatrosses. Polar Biol 14:123-126

Weimerskirch H, Wilson R (2000) Oceanic respite for wandering albatrosses. Nature 406:955-956

Weimerskirch H, Bartle JA, Jouventin P, Stahl JC (1988) Foraging ranges and partitioning of feeding zones in three species of southern albatrosses. Condor 90:214-219

Weimerskirch $H$, Salamolard M, Sarrazin F, Jouventin P (1993) Foraging strategy of wandering albatrosses through the breeding season: a study using satellite telemetry. Auk 110:325-342

Weimerskirch H, Catard A, Prince PA, Cherel Y, Croxall JP (1999) Foraging white-chinned petrels Procellaria aequinoctialis at risk: from the tropics to Antarctica. Biol Conserv 87:273-275

White RW, Reid JB, Black AD, Gillon KW (1999) Seabird and marine mammal dispersion in the waters around the Falkland Islands 1998-1999. Joint Nature Conservation Committee, Peterborough

Wood AG, Naef-Daenzer B, Prince PA, Croxall JP (2000) Quantifying habitat use in satellite-tracked pelagic seabirds: application of kernel estimation to albatross locations. J Avian Biol 31:278-286

Wood KA (1992) Seasonal abundance and spatial distribution of albatrosses off central New South Wales. Aust Bird Watcher 14:207-225

Xavier JC, Rodhouse PG, Trathan PN, Wood AG (1999) A geographical information system (GIS) atlas of cephalopod distribution in the Southern Ocean. Antarct Sci 11:61-66

Submitted: August 7, 2001; Accepted: November 22, 2001 Proofs received from author(s): March 26, 2002 